\title{
Antifungal activity and inhibition of aflatoxins production by Zingiber officinale Roscoe essential oil against Aspergillus flavus in stored maize grains
}

\author{
Samuel Botião Nerilo ${ }^{1}$ Jéssica Cristina Zoratto Romoli ${ }^{1}$ Lydiana Polis Nakasugi $^{1}$ \\ Natana Souza Zampieri ${ }^{1}$ Simone Aparecida Galerani Mossini ${ }^{1}$ Gustavo Henrique Oliveira Rocha ${ }^{2}$ \\ Eduardo Micotti da Gloria ${ }^{3}$ Benício Alves de Abreu Filho ${ }^{1}$ Miguel Machinski Jr$^{1 *}(\mathbb{D}$
}

${ }^{1}$ Departamento de Ciências Básicas da Sáude, Universidade Estadual de Maringá (UEM), 87020-900, Maringá, PR, Brasil. E-mail: mmjunior@uem.br. *Corresponding author.

${ }^{2}$ Departamento de Análise Clínicas e Toxicológicas, Universidade de São Paulo (USP), São Paulo, SP, Brasil.

${ }^{3}$ Escola Superior de Agricultura Luiz de Queiroz (Esalq), Universidade de São Paulo (USP), Piracicaba, SP, Brasil.

ABSTRACT: Essential oils are possible alternatives to the use of synthetic pesticides for control of fungal contamination. Ginger (Zingiber officinale) essential oil (GEO) is known for having antifungal and antiaflatoxigenic properties, but its use as a fumigant in situ has not been studied yet. The aim of this study was to evaluate GEO's effects upon Aspergillus flavus as a fumigant agent in stored maize grains. The main compounds reported in GEO were $\alpha$-zingiberene (23.85\%) and geranial (14.16\%), characterized by gas chromatography-mass spectrometry and nuclear magnetic resonance. The GEO was used as a fumigant in irradiated maize grains in concentrations ranging from 5 to $50 \mu g / g$ and the resulting effects were compared to a synthetic antifungal agent (carbendazim and thiram), an antifungal traditionally used for seed treatment. The antifungal efficacy of GEO against A. flavus has been proven in a dose-dependent manner through in situ (maize grains) test. The GEO inhibited aflatoxin production at concentrations 25 and $50 \mu \mathrm{g} / \mathrm{g}$ and controlled fungal growth. Therefore, GEO can be used as an effective and non-toxic alternative to conventional treatments in stored maize grains for the natural control of A. flavus.

Key words: aflatoxins, posthaverst, fumigants, maize, essential oils.

Atividade antifúngica e inibição da produção de aflatoxinas pelo óleo essencial de Zingiber officinale Roscoe contra Aspergillus flavus em grãos de milho armazenados

RESUMO: Os óleos essenciais são possiveis alternativas ao uso de praguicidas sintéticos no controle da contaminação por fungos. O óleo essencial de gengibre (Zingiber officinale - OEG) é conhecido por possuir propriedades antifúngicas e antiaflatoxigênicas, mas seu uso como fumigante in situ ainda não foi estudado. O objetivo deste estudo foi avaliar os efeitos do OEG sobre Aspergillus flavus como agente fumigante em grãos de milho armazenados. Os principais compostos encontrados no OEG foram $\alpha$-zingibereno (23,85\%) e geranial (14,16\%), caracterizados por cromatografia gasosa acoplada a espectrometria de massas e ressonância magnética nuclear. O OEG foi utilizado como fumigante em grãos de milho irradiados em concentrações variando de 5 a $50 \mu \mathrm{g} / \mathrm{g}$ e os efeitos resultantes foram comparados a um agente antifúngico sintético (carbendazim e tiram), antifúngico tradicionalmente usado para o tratamento de sementes. A eficácia antifúngica do OEG contra A. flavus foi comprovada de maneira dependente da dose através do teste in situ (grãos de milho). O OEG inibiu a produção de aflatoxina nas concentrações 25 e $50 \mu \mathrm{g} / \mathrm{g}$ e controlou o crescimento de fungos. Portanto, o OEG pode ser usado como uma alternativa eficaz e não tóxica aos tratamentos convencionais em grãos de milho armazenados para o controle natural de A. flavus.

Palavras-chave: aflatoxinas, pós-colheita, fumigantes, milho, oleos essenciais.

\section{INTRODUCTION}

Produce and other food goods can be frequently contaminated by fungi and toxins produced by them during transport, storage or post-harvest processing (MEDINA et al., 2015). Contamination causes significant losses of quality, quantity and nutritional profile, and thus it decreases market value of such goods. The Food and Agriculture Organization (FAO) estimates that $25 \%$ of grains produced worldwide are contaminated by mycotoxins and 1000 million tons of grains by fungi-produced mycotoxins during storage each year (BHAT et al., 2010). Mycotoxins have become a worldly problem 
not only to developing countries anymore, once the ingestion of such mycotoxin contaminated foods can cause serious impacts upon animal and human health, reduce agricultural production and create barriers amidst the international grain commerce relationships (BRYDEN, 2012).

The aflatoxigenic species of Aspergillus from section Flavi, such as Aspergillus flavus and Aspergillus parasiticus, are particularly important, as they damage crops before and after harvest or during storage (BHATNAGAR \& GARCIA, 2013). Several agricultural products may be affected by aflatoxins (AFs), as rice, maize, groundnuts, spices and dried fruits, resulting in severe economic losses for farmers and food industries, and serious risks to human and animal health (RUSHING \& SELIM, 2019). The studies investigating maize contamination saw an average frequency of $46.1 \%$ of samples positive for aflatoxin $\mathrm{B}_{1}\left(\mathrm{AFB}_{1}\right)$ and an average maximum concentration of $553.9 \mu \mathrm{g} / \mathrm{kg}$ (RUSHING \& SELIM, 2019). $\mathrm{AFB}_{1}$ is secondary metabolite with genotoxic, immunotoxic and hepatocarcinogenic (hepatocellular carcinoma - HCC) properties, classified as human carcinogens belonging to group 1 according to the International Agency for Research on Cancer (IARC, 2012).

Several strategies aimed to control of postharvest fungal, various physical and chemical treatment, chemical fungicides and sulfur dioxide fumigation are being adopted. However, these physical and chemical methods have their own limitations (SONKER et al., 2014). Their use in food commodity storage has had linked to fungal resistance and new secondary pests have surfaced due to carelessness and excessive use of chemicals (CABRAL et al., 2013). Such misuse of chemicals has increased the levels of toxic residues of synthetic fungicides on foods and on the environment (SONKER et al., 2014). Essential oils (EOs) from aromatic plants might be an alternative to the usage of synthetic chemicals due to their antifungal activity against Aspergillus and other fungi, inhibiting mycelium growth, spore germination and aflatoxin production (FERREIRA et al., 2013; KOHIYAMA et al., 2015; NERILO et al., 2016). The EOs can be easily acquired at low costs and do not possess the same problems inherent to synthetic chemical pesticides (CABRAL et al., 2013; SONKER et al., 2014). As such, the search for new natural antifungal compounds for use on field crops, stored goods and food conservation has increased in the last years (CABRAL et al., 2013; SONKER et al., 2014; FERREIRA et al., 2013; KOHIYAMA et al., 2015; NERILO et al., 2016).
Metabolites synthetized by plants are a promising alternative, once plants produce a great variety of compounds, be it as part of their natural development or as a response to stress or pathogens. Ginger (Zingiber officinale Roscoe) was one of the first fine species known in the East as a medicinal plant (YU et al., 2007). Bioactive compounds responsible for ginger's therapeutic potential, as well as its smell and taste, are extracted from its rhizome's EO (AGARWAL et al., 2001; SINGH et al., 2008). The fact that EOs are constituted from a great variety of compounds confers ginger other advantages, such as different modes of action, depending on the compound, which causes ginger's EO to be effective against different genders of fungi, also preventing the target fungi to develop resistance (RUSHING \& SELIM, 2019). Previously, we have demonstrated that ginger's EO possess a strong antifungal activity against A. flavus "in vitro", as indicated by the variations caused on fungal structures size and on mycelium mass, alterations on conidia morphology and production and inhibitory effects on ergosterol and aflatoxin production (NERILO et al., 2016).

EOs can be easily employed as botanical fumigants on agricultural produce with the aid of modern capsuling technology. The EOs are natural substances classified as GRAS (Generally Recognized as Safe) by the US Food and Drug Administration (FDA) due to antibacterial, antifungal and antioxidant properties, which indicated that they can be used in food industry (FDA, 2012). Fumigation is one of the best methods in order to avoid contamination by pests during storage without leaving residual effects (PRAKASH et al., 2014). Therefore, the present study evaluated the effects of essential oil obtained from $Z$. officinale as a fumigant agent against the growth of A. flavus and production of aflatoxins on stored maize grains.

\section{MATERIALS AND METHODS}

\section{Extraction and characterization of $Z$. officinale essential oil}

Ginger essential oil (GEO) was obtained by hydrodistillation using a Clevenger apparatus. Ginger rhizomes $(200 \mathrm{~g})$ acquired from a local market were placed in the apparatus alongside $500 \mathrm{~mL}$ of distilled water for extraction, resulting in approximately 500 $\mu \mathrm{L}$ of essential oil after 3 hours of distillation at 70 ${ }^{\circ} \mathrm{C}$. After GEO was obtained, residual water was removed with anhydrous sodium sulfate (Labsynth ${ }^{\circledR}$, Diadema, Brazil). The obtained GEO was stored at 4 ${ }^{\circ} \mathrm{C}$ inside an amber flask until used. 
The chemical composition of GEO was analyzed by gas chromatography coupled to mass spectrometry (GC/MS) and nuclear magnetic resonance (NMR), according ADAMS (2007) and subsequently published by NERILO et al. (2016). In this study, the major components were identified as $\alpha$-zingiberene, geranial, $\alpha$-farnesene, camphene, $\beta$-phellandrene and neral (Table 1).

\section{Microorganisms and culture conditions}

A. flavus (AF42) was obtained from a collection of other isolated fungi stored in the Toxicology Laboratory of the State University of Maringa. The strains were kept in recipients containing silica inside refrigerators at $4{ }^{\circ} \mathrm{C}$. For conidia production, the fungi were cultivated in potato-dextrose-agar (PDA) (Neogen ${ }^{\circledR}$ Co., Lasing, MI, USA) for 7 days at $25^{\circ} \mathrm{C}$, under no natural or artificial light, inside a BOD incubator (AGARWAL et al., 2001).

\section{GEO working solutions}

GEO was diluted in acetone in order to obtain solutions at concentrations of 5,25 and $50 \mu \mathrm{g} /$ $\mathrm{mL}$, which refer to a concentration below the minimal inhibitory concentration (MIC), to the MIC, and to a concentration above the MIC, as determined by previous studies (NERILO et al., 2016).

\section{Inoculum preparation}

After fungal sporulation, an aqueous sterile solution prepared with Tween $80(0.1 \%)$ containing $10^{6}$ conidia $/ \mathrm{mL}$ was prepared. The amount of conidia was determined by optical microscopy (Nikon Instruments Inc., São Paulo, Brazil) with the aid of a Neubauer chamber.

\section{Substrate preparation}

The substrate of choice was maize grains irradiated with $12 \mathrm{kGy}$ of gamma radiation and then aseptically stored at $4{ }^{\circ} \mathrm{C}$, which allowed the grains to keep their germination properties. Initially, the activity of water (Aw) measured on the grains was 0.78. In all experiments, the irradiated maize grains were weighted in sterile flasks and hydrated until they reached the desired Aw levels (0.85) by adding sterile distilled water. Flasks were kept at $4{ }^{\circ} \mathrm{C}$ during 48 hours, being periodically agitated. The amount of water required in order to obtain the desired Aw levels was determined by calibration curves according SAMAPUNDO et al. (2007). The final Aw values of the maize grains were verified by an AquaLab 3 device (Decagon Devices Inc., Pullman, WA, USA), and showed a precision of \pm 0.003 .

\section{In vivo fumigant efficacy of GEO against A. flavus in maize grains}

Five sterile flasks containing $300 \mathrm{~g}$ of irradiated and rehydrated maize grains each were used: fungal control, positive control and 3 different treatments with GEO at 5,25 and $50 \mu \mathrm{g} / \mathrm{g}$. On all flasks containing maize grains, with the exception of the negative controls, $10 \mathrm{~mL}$ of Tween 80 solution containing A. flavus inoculums were pulverized. Later, $1.8 \mathrm{~mL}$ of acetone were pulverized on the fungal control, $1.8 \mathrm{~mL}$ of Derosal Plus ${ }^{\circledR} 30 \mu \mathrm{g} / \mathrm{g}$ (carbendazim and tiram) in acetone on the positive control and 1.8 $\mathrm{mL}$ of oil solution were pulverized on the treatments. Next, each flask containing maize grains with their respective treatments were fractioned in six portions of $50 \mathrm{~g}$ each. On these fractions a saline solution was added in order to create an environment with the same relative humidity. Storage was performed

Table 1 - Major compounds of Zingiber officinalis Roscoe essential oil (GEO).

\begin{tabular}{lccr}
\hline Compounds & RI $^{*}$ & Percentage (\%) & Identification method \\
\hline$\alpha$-Zingiberene & 29.55 & 23.85 & GC/MS, NMR \\
Geranial & 20.12 & 14.16 & GC/MS, NMR \\
$\alpha$-Farnesene & 30.06 & 9.98 & GC/MS, NMR \\
Camphene & 7.26 & 8.43 & GC/MS, NMR \\
$\beta$-Phellandrene & 9.97 & 8.23 & GC/MS \\
Neral & 18.83 & 7.47 & GC/MS \\
\hline
\end{tabular}

Source: Nerilo et al. (2016).

GC/MS - gas chromatography / mass spectrometry. NMR - nuclear magnetic ressonance.

*Retention Index obtained with different standards from the n-alkanes series $\mathrm{C}_{8} \mathrm{H}_{18}-\mathrm{C}_{20} \mathrm{H}_{42}$ in column DB-5. 
in recipients hermetically closed for fumigation, with relative humidity being controlled by a BOD incubator (FANEM, model 347 G, Sao Paulo, Brazil) at $27^{\circ} \mathrm{C}$ for 15 days. After this incubation period, the flasks were taken out for evaluation of fungal growth and mycotoxin production.

\section{Inhibition of $A$. flavus growth}

The inhibition of A. flavus growth was determined by counting the colony forming units (CFI) observed after surface plating, which was performed diluting $50 \mathrm{~g}$ of sample in $200 \mathrm{~mL}$ of peptonated water $0.1 \%(1 / 10)$. Further dilutions of 1:100, 1:1000 and 1:10000 were also made. From each dilution, $100 \mu \mathrm{L}$ aliquots were transferred to Petri dishes containing Dichloran Rose-Bengal Chloramphenicol Agar - DRBC, in triplicates. The Petri dishes were kept in an incubator for 5 days at 25 ${ }^{\circ} \mathrm{C}$. Next, the existing colonies were counted in order to determine the $\mathrm{CFI} / \mathrm{mL}$, which was determined by counting the number of CFI and multiplying the result by the dilution used in the respective sample. Next, the CFI inhibition percentage was determined by the following formula: IP $(\%)=[(\mathrm{nc}-\mathrm{dt}) / \mathrm{nc}] \times 100$, where $n c$ is the control average counting of $\mathrm{CFI} / \mathrm{mL}$ and $d t$ is the treatment average counting of CFI $/ \mathrm{mL}$.

\section{Inhibition of aflatoxins production}

From each treatment and control, 50 $\mathrm{g}$ were taken out for aflatoxin extraction and later determination by high efficiency liquid chromatography (HPLC).

\section{Aflatoxins standards}

Stock solutions of each $\mathrm{B}_{1}$ and $\mathrm{B}_{2}$ aflatoxins were prepared by diluting the $\mathrm{AFB}_{1}$ and $\mathrm{AFB}_{2}$ standards in the same benzene-acetonitrile solution at concentrations of $5 \mu \mathrm{g} / \mathrm{mL}$ for each aflatoxin. All reagents and solvents were obtained from Honeywell Burdick \& Jackson (Muskegon, MI, USA), Fisher Scientific (Fair Lawn, NJ, USA), Mallinckrodt Baker (Xalostoc, Mexico), FMaia (Cotia, Brazil), Merck (Darmstadt, Germany) and Labsynth (Diadema, Brazil). A standard solution containing a mixture of $\mathrm{AFB}_{1}$ and $\mathrm{AFB}_{2}$ was used to obtain a calibration curve with 7 points representing concentration as a function of area.

\section{Extraction and quantification of aflatoxins}

$\mathrm{AFB}_{1}$ and $\mathrm{AFB}_{2}$ were analyzed according to the method by SOARES \& RODRIGUEZAMAYA (1989) with modifications. From each sample, $50 \mathrm{~g}$ were taken out and put in a mixer
(Waring Co., Torrington, CT, USA) with $270 \mathrm{~mL}$ of methanol (Synth, Diadema, Brazil) and $30 \mathrm{~mL}$ of potassium chloride $4 \%$ (Synth), and then mixed for 5 minutes until a homogeneous solution was obtained. The mixture was filtered through a qualitative filter paperand $150 \mathrm{~mL}$ of the filtered solution were transferred to a new recipient. After that, $150 \mathrm{~mL}$ of ammonium sulfate 30\% (Nuclear, Diadema, Brazil) and $20 \mathrm{~g}$ of celite (Nuclear) were added to the mixture, which was left still at room temperature for $5 \mathrm{~min}$. The mixture was then filtered through a qualitative filter paper, and $150 \mathrm{~mL}$ of the filtered solution were transferred to another recipient and $150 \mathrm{~mL}$ of water were added to this solution. This mixture was fractioned twice with $10 \mathrm{~mL}$ of chloroform (Vetec, Duque de Caxias, Brazil); $5 \mathrm{~mL}$ from both the first and second chloroform partitions were combined and evaporated until they dried out in a water bath at $60^{\circ} \mathrm{C}$ (EVLAB, model 015T, Londrina, Brazil). The residue was kept at $-18^{\circ} \mathrm{C}$ until the moment of further analysis.

The analyses of aflatoxins $\left(\mathrm{AFB}_{1}\right.$ and $\mathrm{AFB}_{2}$ ) were carried out by a HPLC apparatus Finnigan Surveyor (Thermo, Scientific, San Jose, CA, USA), equipped with a fluorescence detection system Finnigan Surveyor. The excitation wavelength was $430 \mathrm{~nm}$ and the emission wavelength was $365 \mathrm{~nm}$. The residues were resuspended in $1 \mathrm{~mL}$ of methanol (F. Maia Indústria e Comércio Ltda., Cotia, Brasil), filtered through a $0.45 \mu \mathrm{m}$ membrane (EMD Millipore Corporation, Billerica, MA, USA), and $100 \mu \mathrm{L}$ of each suspension were injected in the chromatographic system. The mobile phase was composed of wateracetonitrile $(65: 35, \mathrm{v} / \mathrm{v})$, and the flow rate was of 1 $\mathrm{mL} / \mathrm{min}$. The mobile phase was also filtered through a $0.45 \mu \mathrm{m}$ membrane (EMD Millipore Corporation, Billerica, MA, USA). The chromatographic column was a $\mathrm{C}_{18}$ Pickering $5 \mu \mathrm{m}(250 \times 4.6 \mathrm{~mm}$, Pickering Laboratories $^{\circledR}$, Mountain View, CA, USA). The retention time was 10 and $13 \mathrm{~min}$ for $\mathrm{AFB}_{2}$ and $\mathrm{AFB}_{1}$, respectively. The quantification limits of the samples were 33 and $100 \mathrm{ng} / \mathrm{mL}$ for $\mathrm{AFB}_{2}$ and $\mathrm{AFB}_{1}$, respectively. The aflatoxin average recovery ratio was $85.5 \%$. Lastly, the inhibition percentage was calculated according to the following formula: inhibition $(\%)=(1$-treatment/control $) \times 100 \%$.

Figure 1 shows a flowchart of the methodology used to evaluate the antifungal and antimicotoxygenic activity of essential oils in fumigation of maize grains "in situ".

\section{Statistical analysis}

The results were expressed as mean \pm standard deviation and analyzed by Student's test 


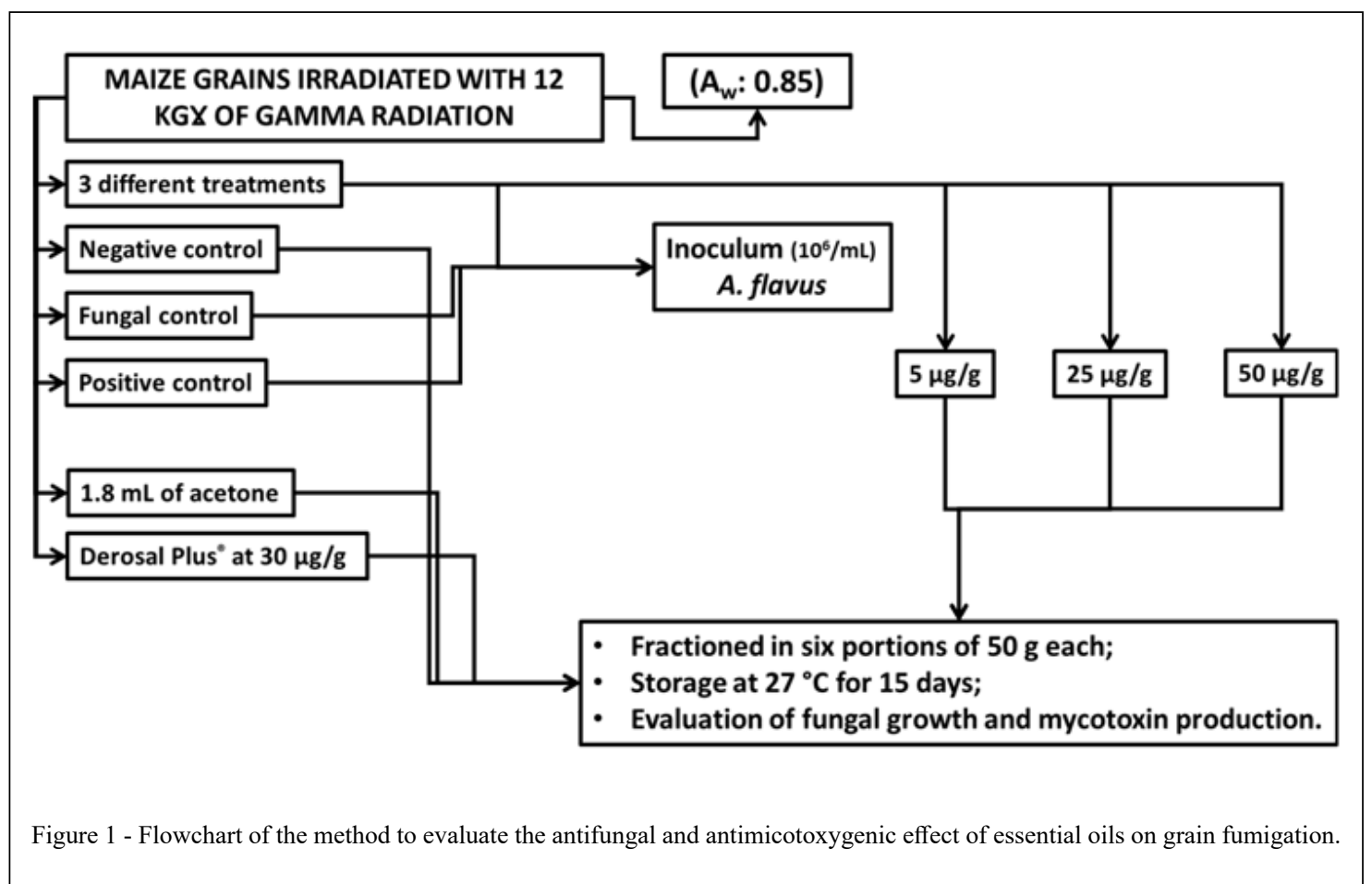

when two means were compared or by one way analysis of variance (ANOVA) when multiple means were compared, followed by Tukey post-hoc test. All statistical analyses were performed using the software GraphPad Prism 6 (GraphPad Software, Inc.).

\section{RESULTS AND DISCUSSION}

Results obtained from the GC-MS and NMR analysis are shown in table 1. The main compounds reported in GEO were $\alpha$-zingiberene $(23.85 \%)$ and geranial $(14.16 \%)$. Other compounds reported in relevant quantities were $\alpha$-farnesene (9.98\%), camphene (8.43\%), B-phellandrene (8.23\%) and neral $(7.47 \%)$. Other chemical compounds were also observed, but present in smaller concentrations (NERILO et al., 2016). Therefore, there is a good correlation with other studies which also point $\alpha$-zingiberene as the main compound of GEO, even if others can be reported as constituting the majority, such as geranial or gingerol (DABAGUE et al., 2011). It is reported that variations in both quantity and quality of polyphenols found in aromatic plants occur due to several factors, such as plant genetics and cultivars, the composition of soil and growth conditions, growth stage and post-harvest conditions
(AGARWAL et al., 2001; DABAGUE et al., 2011; SONKER et al., 2014; KOHIYAMA et al., 2015).

In this study, we present evidence that fumigation with GEO displays high antifungal activity against $A$. flavus. It was possible to determine that all tested concentrations demonstrated high rates of fungal growth inhibition, and that for the 25 and $50 \mu \mathrm{g} / \mathrm{g}$ GEO concentrations such inhibition was complete after 14 days of incubation (Table 2). THANABORIPAT et al. (2004) demonstrated that citronella EO at a $1000 \mu \mathrm{g} / \mathrm{g}$ inhibited $A$. flavus growth for no more than 3 days, while it was completely inhibited for 28 days at a citronella EO concentration of $5000 \mu \mathrm{g} / \mathrm{g}$. PASSONE et al. (2013) observed inhibitions of $93-100 \%$ upon A. flavus when using doses superior to $1.5 \mu \mathrm{g} / \mathrm{g}$ of boldo essential oil after $300 \mathrm{~h}$ of incubation at Aw of 0.98, 0.95 and 0.93 . Only the highest concentration evaluated (3000 $\mu \mathrm{g} / \mathrm{g}$ ) of five EOs of Pimpinella anisum L. (anisseed), Pneumus boldus Mol (boldo), Hedeoma multiflora Benth (mountain thyme), Syzygium aromaticum L. (clove) and Lippia maizeeto var. Integrifolia (Griseb) demonstrated the ability to maintain antifungal activity for an incubation period of 35 days in maize grains (BLUMA \& ETCHEVERRY, 2008). The Artemisia nilagirica EO enhanced the shelf life of 
table grapes for up to nine days against A. flavus, $A$. niger and $A$. ochraceus with $300 \mu \mathrm{g} / \mathrm{g}$ (SONKER et al., 2014). The Rosmarinus officinalis EO at a 1500 $\mu \mathrm{g} / \mathrm{g}$ significantly protected Piper nigrum fruits against $A$. flavus up to 6 months in vivo experiment (PRAKASH et al., 2015).

There was a significant reduction of aflatoxins produced by $A$. flavus in all GEO concentrations evaluated (Table 2, Figure 2). The traditionally used antifungal for seed treatment as well as different GEO concentrations reduced aflatoxin production, the concentrations of 25 and 50 $\mu \mathrm{g} / \mathrm{g}$ of GEO being the most efficient (Figure 3 ).

GEO showed a dose-dependent antifungal activity. However, it did not show any antimycotoxigenic effect, as the reduction of aflatoxin production seen in higher concentrations occurred due to the great reduction in the amount of viable cells $(\mathrm{CFI} / \mathrm{mL})$, as shown in figure 3 and table 2 .

Other authors also demonstrated the fumigant effect of EOs with antifungal and antimycotoxigenic actions. In maize grains, SINHA et al. (1993) showed that cinnamon and clove EOs were capable of inhibiting aflatoxin production by A. flavus after 10 days under favorable conditions for aflatoxin production. PASSONE et al. (2013) observed inhibition of $100 \%$ at concentrations of $1.5 \mu \mathrm{g} / \mathrm{g}$ of boldo EO applied to nuts for an incubation period of $300 \mathrm{~h}$. THANABORIPAT et al. (2004) demonstrated that aflatoxin production on maize grains was inhibited for only 3 days at a concentration of $10 \mu \mathrm{g} / \mathrm{g}$ of citronella $\mathrm{EO}$, while $\mathrm{AFB}_{1}$ production was completely inhibited for 28 days at a concentration of $50 \mu \mathrm{g} / \mathrm{g}$.

We demonstrated in previous studies that GEO at $15 \mu \mathrm{g} / \mathrm{g}$ was capable of reducing fungal growth and production of $\mathrm{AFB}_{1}$ and $\mathrm{AFB}_{2}$ almost completely (98.1 to $99.9 \%$ inhibition) in vitro (NERILO et al., 2016). However, the required concentrations in order to control fungal growth and production of $\mathrm{AFB}_{1}$ and $\mathrm{AFB}_{2}$ in sterilized maize grains were way higher $(25$ to $50 \mu \mathrm{g} / \mathrm{g})$. These findings were similar to the ones reported by MONTES-BELMONT \& CARVAJAL (1998), HOPE et al. (2003) and BLUMA and ETSCHEVERRY (2008). HOPE et al. (2002) suggested that extrapolation of results obtained from in vitro experiments to in situ experiments must be cautious; they attributed special importance to the fact that, while low concentrations ( 50 to $100 \mu \mathrm{g} / \mathrm{g}$ ) of different EOs were efficient in vitro, concentrations way higher than $500 \mu \mathrm{g} / \mathrm{g}$ were necessary in order to control the growth of F. culmorum in sterilized wheat grains in situ.

Some researchers reported that there is a correlation between the chemical structures of the most abundant compounds found in EOs and their antimicrobial activity (MONTES-BELMONT \& CARVAJAL, 1998; AGARWAL et al., 2001;

Table 2 - Fumigant effect of the different Zingiber officinale Roscoe (GEO) concentrations on maize grains upon Aspergillus flavus and aflatoxins production $\left(\mathrm{AFB}_{1}\right.$ and $\left.\mathrm{AFB}_{2}\right)$.

\begin{tabular}{|c|c|c|c|}
\hline $\begin{array}{l}\text { [ ] GEO } \\
(\mu \mathrm{g} / \mathrm{g})\end{array}$ & $\begin{array}{c}\mathrm{CFI} / \mathrm{mL} \\
\text { (\% of inhibition) }\end{array}$ & \multicolumn{2}{|c|}{ L-10 } \\
\hline & & $\mathrm{AFB}_{1}$ & $\mathrm{AFB}_{2}$ \\
\hline $\mathrm{FC}$ & $2.5 \times 10^{6}$ & $26986.54 \pm 1004.99$ & $1419.12 \pm 104.60$ \\
\hline $\mathrm{CP}$ & $\begin{array}{l}8.0 \times 10^{2 \mathrm{a}} \\
(99.97)\end{array}$ & $12353.09 \pm 145.66(54.22)^{\mathrm{a}, \mathrm{b}}$ & $\begin{array}{c}521.73 \pm 10.55 \\
(63.24)^{\mathrm{a}}\end{array}$ \\
\hline 5 & $\begin{array}{l}3.3 \times 10^{3 \mathrm{a}} \\
(99.87)\end{array}$ & $12428.38 \pm 110.08(53.95)^{\mathrm{a}, \mathrm{b}}$ & $831.93 \pm 25.17(41.38)$ \\
\hline 25 & $\begin{array}{c}4.0 \times 10^{0 \mathrm{a}, \mathrm{b}} \\
(99.99)\end{array}$ & $1744.09 \pm 90.03(93.54)^{\mathrm{a}, \mathrm{c}}$ & $\begin{array}{c}95.51 \pm 1,53 \\
(93.27)^{\mathrm{a}, \mathrm{d}}\end{array}$ \\
\hline 50 & $\begin{array}{c}4.0 \times 10^{0 \mathrm{a}, \mathrm{b}} \\
(99.99)\end{array}$ & $1554.53 \pm 80.13(94.24)^{a, c}$ & $\begin{array}{c}90.83 \pm 1,06 \\
(93.60)^{a, d}\end{array}$ \\
\hline
\end{tabular}

FC: fungal control (inoculum without GEO or synthetic fungicide).

PC: positive control (Derosal Plus ${ }^{\circledR} 30 \mu \mathrm{g} / \mathrm{g}$ ).

a: statistically different from control $(\mathrm{P}<0.05)$.

b: statistically equal between themselves $(\mathrm{P}>0.05)$.

c: statistically equal between themselves $(\mathrm{P}>0.05)$.

$\mathrm{d}$ : statistically equal between themselves $(\mathrm{P}>0.05)$. 


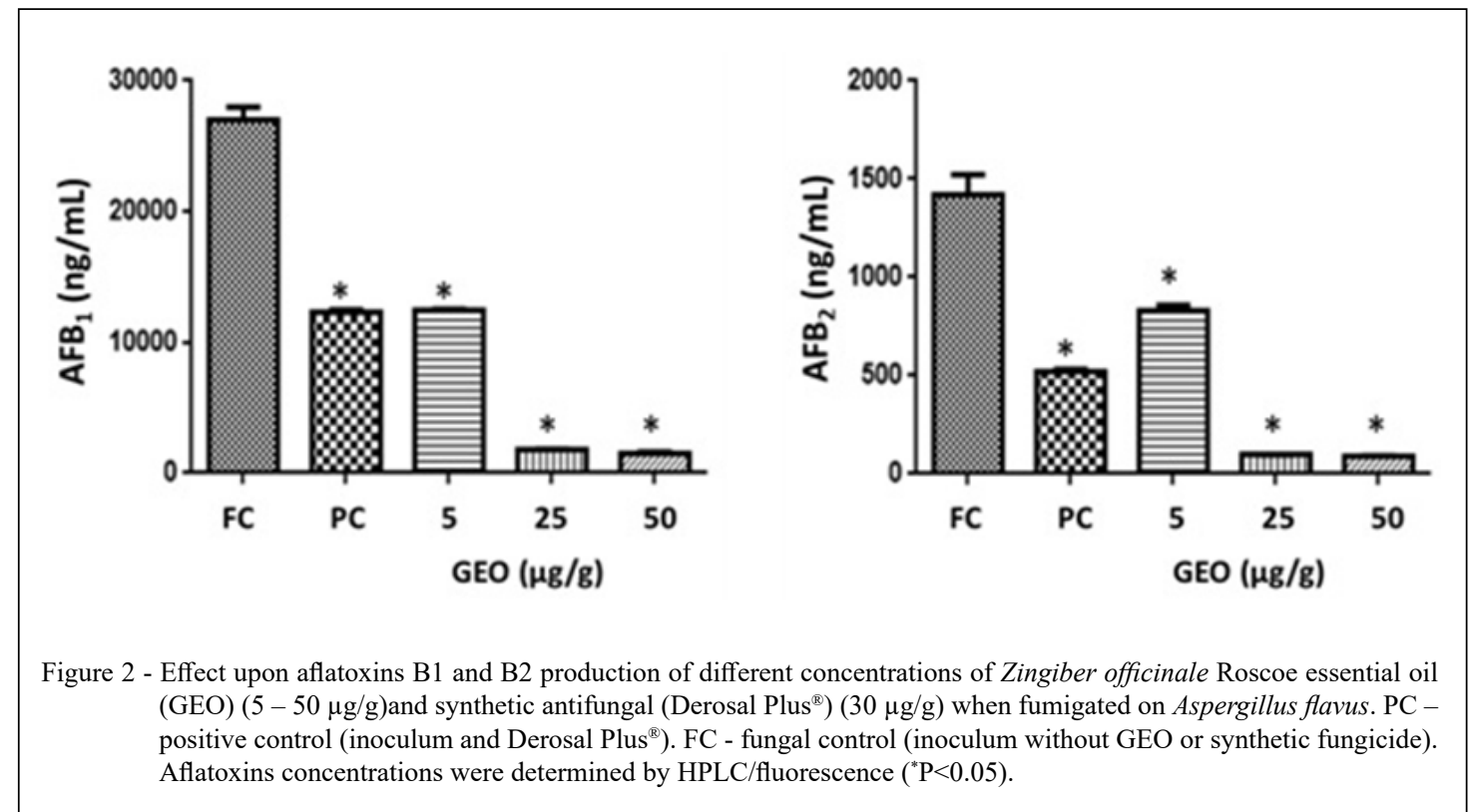

FERREIRA et al., 2013; PRAKASH et al., 2015; WANG et al., 2018; LASRAM et al., 2019). There are evidences showing that secondary compounds play an important role in assuring antimicrobial activity of EOs, possibly due to a synergistic effect that emerges from the interaction with other secondary compounds (PRAKASH et al., 2015; WANG et al., 2018;
LASRAM et al., 2019). Considering the extensive number of different chemical compounds in EOs, the most probable theory is that their antimicrobial activities are not attributable to a single specific mechanism, but rather to the existence of several cell targets (PRAKASH et al., 2015; WANG et al., 2018; LASRAM et al., 2019). WANG et al. (2018) and



Ciência Rural, v.50, n.6, 2020. 
LASRAM et al. (2019) also observed differences in antifungal and anti-mycotoxigenic activities of EOs as a whole when compared to some of their major chemicals when isolated.

The first step in fighting fungal contamination refers to applying fungicides on the field. Fungicides can be applied post-harvest, as long as they do not harm the appearance or the quality of the treated products. However, the excessive use of fungicides on crops has been one of the main causes for development of resistant plant pathogens, which results in the use of even higher concentrations of such fungicides and the inevitable increase of toxic residues on produce. We demonstrated promising results showing that fumigation with GEO was comparable in efficiency with Derosal Plus ${ }^{\circledR}$ (a contact and systemic fungicide from groups benzimidazole and dimethyldithiocarbamate), traditionally used for the treatment of maize seeds, inhibiting the development of A. flavus and consequently reducing the contamination with $\mathrm{AFB}_{1}$ and $\mathrm{AFB}_{2}$ on the maize used in the experiment.

\section{CONCLUSIONS}

These results clearly indicate that GEO should find practical use as an antifungal agent and therefore be capable of reducing aflatoxins contamination in stored maize grains. The antifungal efficacy of GEO against A. flavus was demonstrated in a dose-dependent manner through in situ test (maize grains). GEO inhibited aflatoxin production and controlled fungal growth at concentrations 25 and $50 \mu \mathrm{g} / \mathrm{g}$, respectively. The advantage that GEO and other EOs possess is that they are bioactive even as fumes, which makes protection of stored products, such as maize grains, viable. Fumigation with GEO can be used as a environment-friendly fungicide, highly-effective with low MIC, strong fungitoxicity and aflatoxins-inhibiting activity.

\section{ACKNOWLEDGEMENTS}

This study was financed by the Conselho Nacional de Desenvolvimento Científico e Tecnológico (CNPq), Brasil - Grant $480.944 / 2010-5$ and was financed in part by the Coordenação de Aperfeiçoamento de Pessoal de Nível Superior (CAPES), Brasil Finance code 001, Grant 028.054/2009.

\section{DECLARATION OF CONFLICT OF INTERESTS}

The authors declare no conflict of interest. The founding sponsors had no role in the design of the study; in the collection, analyses, or interpretation of data; in the writing of the manuscript, and in the decision to publish the results.

\section{AUTHORS' CONTRIBUTIONS}

SBN, EMG and MMJ designed the study. SBN, JCZR, LPN, GHOR, NSZ and MMJ acquired the data. SBN and MMJ analyzed the data, and SBN, EMG, BAAF and MMJ contributed to the writing of the manuscript. All authors critically revised the manuscript and approved of the final version.

\section{REFERENCES}

ADAMS, R. P. (2007). Identification of Essential Oils Components by Gas Chromatography / Quadrupole Mass Spectrometry. Carol Stream: Allured Publishing Cooperation. Available from: <https://pubs.acs.org/doi/10.1021/ jasms.8b02324>. Accessed: Mar. 16, 2020. doi: 10.1016/j. jasms.2005.07.008.

AGARWAL, M. et al. Insect growth inhibition, antifeedant and antifungal activity of compounds isolated derived from Zingiber officinale Roscoe (ginger) rhizomes. Pest Manager Science, v.57, p.289-300, 2001. Available from: <https://onlinelibrary. wiley.com/doi/full/10.1002/ps.263>. Accessed: Mar. 16, 2020. doi: $10.1002 /$ ps.263.

BHAT, R. et al. Mycotoxins in food and feed: present status and future concerns. Comprehensive Reviews in Food Science and Food Safety, v.9, p.57-81, 2010. Available from: <https:// onlinelibrary.wiley.com/doi/full/10.1111/j.1541-4337.2009.00094. $\mathrm{x}>$. Accessed: Mar. 16, 2020. doi: 10.1111/j.15414337.2009.00094.x.

BHATNAGAR, D., \& GARCIA, S. (2013). Aflatoxins and Aspergillus flavus. In: Labbé, R.G., \& Garcia, S. (Eds.) Guide to Foodborne Pathogens (2nd ed.). Oxford: Wiley-Blackwell, p.257-272. Available from: $<$ https://www.wiley.com/en-usGuide+ to+Foodborne+Pathogens $\% 2 \mathrm{C}+2$ nd+Edition-p-9780470671429>. Accessed: Mar. 16, 2020. ISBN: 978-0-470-67142-9.

BLUMA, R. V.; ETCHEVERRY, M. G. Application of essential oils in maize grain: Impact on Aspergillus section Flavi growth parameters and aflatoxin accumulation. Food Microbiology, v.25, p.324-334, 2008. Available from: <https://www.sciencedirect. com/science/article/pii/S0740002007001098>. Accessed: Mar. 16, 2020. doi: 10.1016/j.fm.2007.10.004.

BRYDEN, W. L. Mycotoxin contamination of the feed supply chain: Implications for animal productivity and feed security. Animal Feed Science and Technology, v.173, p.134-158, 2012. Available from: <https://www.sciencedirect.com/science/article/ pii/S0377840111005037?via\%3Dihub>. Accessed: Mar. 16, 2020. doi: 10.1016/j.anifeedsci.2011.12.014.

CABRAL, L. C. et al. Application of plant derived compounds to control fungal spoilage and mycotoxin production in foods. International Journal of Food Microbiology, v.166, p.1-14, 2013. Available from: <https://www.sciencedirect.com/science/ article/pii/S0168160513002730?via\%3Dihub>. Accessed: Mar. 16, 2020. doi: 10.1016/j.ijfoodmicro.2013.05.026.

DABAGUE, I. C. M. et al. Essential oil yield and composition of ginger (Zingiber officinale Roscoe) rhizomes after different drying periods. Brazilian Jornal of Medicinal Plants, v.13, p.79-84, 2011. 
Available from: <http://www.scielo.br/scielo.php?script=sci_artte xt\&pid=S1516-05722011000100012>. Accessed: Mar. 16, 2020. doi: 10.1590/S1516-05722011000100012.

FDA-Food and Drug Administration. (2012). Foodborne Pathogenic Microorganisms and Natural Toxins. (2nd ed.). Silver Spring: U.S. Department of Health and Human Services. Available from: $<\mathrm{https} / /$ wayback.archive-it.org/7993/20170405001311/https:/www.fda.gov/ Food/FoodborneIllnessContaminants/CausesOfIllnessBadBugBook/ ucm296005.htm>. Accessed: Mar. 16, 2020.

FERREIRA, F. D. et al. Inhibitory effect of the essential oil of Curcuma longa $\mathrm{L}$. and curcumin on aflatoxin production by Aspergillus flavus Link. Food Chemistry, v.136, p.789-793, 2013. Available from: <https://www.sciencedirect.com/science/article/ pii/S0308814612012770?via\%3Dihub>. Accessed: Mar. 16, 2020. doi: $10.1016 /$ j.foodchem.2012.08.003.

HOPE, R., JESTOI, M.; MAGAN, N. (2002). Multitarget environmental approach for control of growth and toxin production by Fusarium culmorum using essential oil and antioxidant. In: CREDLAND, P. F.; ARMITAGE, D. M.; BELL, C. H.; COGAN, P. M.; HIGHLEY, E. (Eds.) Advances in Stored Product Protection. Proceedings of Eighth International Working conference on Stored Product Protection (IWCSPP). New York: CABI Publishing, p.486-492. Available from: <https:// www.semanticscholar.org/paper/Multitarget-environmentalapproach-for-control-of-Hope-Jestoi/9535a4c5a284f56024 65231e22208fd97cee50ca>. Accessed: Mar. 16, 2020. doi: $10.1079 / 9780851996912.0486$.

IARC - International Agency for Research on Cancer. (2012). IARC monographs on the evaluation of carcinogenic risks to humans: Chemical agents and related occupations: A review of human carcinogens. Lyon: IARC SCI Publ, 628p. Available from: <http://publications.iarc.fr/Book-And-Report-Series/IarcMonographs-On-The-Identification-Of-Carcinogenic-HazardsTo-Humans/Chemical-Agents-And-Related-Occupations-2012>. Accessed: Mar. 16, 2020. ISBN: m978-92-832-0138-0.

KOHIYAMA, C. Y. et al. Antifungal properties and inhibitory effects upon aflatoxin production of Thymus vulgaris L. by Aspergillus flavus Link. Food Chemistry, v.173, p.1006-1010, 2015. Available from: <https://www.sciencedirect.com/science/ article/pii/S0308814614017099?via\%3Dihub>. Accessed: Mar. 16, 2020. doi: 10.1016/j.foodchem.2014.10.135.

LASRAM, S. et al. Antifungal and antiaflatoxigenic activities of Carum carvi L., Coriandrum sativum L. seed essential oils and their major terpene component against Aspergillus flavus. Industrial Crops and Products, v.134, p.11-18, 2019. Available from: <https://www.sciencedirect.com/science/ article/pii/S0926669019301943>. Accessed: Mar. 16, 2020. doi: $10.1016 /$ j.indcrop.2019.03.037.

MEDINA, A. et al. Climate change factors and Aspergillus flavus: effects on gene expression, growth and aflatoxin production. World Mycotoxin Journal, v.8, p.171-179, 2015. Available from: <https://www.wageningenacademic.com/doi/abs/10.3920/ WMJ2014.1726>. Accessed: Mar. 16, 2020. doi: 10.3920/ WMJ2014.1726

MONTES-BELMONT, R.; CARVAJAL, M. Control of Aspergillus flavus in maize with plant essential oils and their components. Journal of Food Protection, v.61, p.616-619, 1998. Available from: <https://meridian.allenpress.com/jfp/ article-lookup/doi/10.4315/0362-028x-61.5.616>. Accessed: Mar. 16, 2020. doi: 10.4315/0362-028x-61.5.616.

NERILO, S. B. et al. Antifungal properties and inhibitory effects upon aflatoxin production by Zingiber officinale essential oil in Aspergillus flavus. International Journal of Food Science and Technology, v.51, p.286-292, 2016. Available from: $<$ https://onlinelibrary.wiley.com/doi/full/10.1111/ijfs.12950>. Accessed: Mar. 16, 2020. doi: 10.1111/ijfs.12950.

PASSONE, M. A. et al. Antifungal and antiaflatoxigenic activity by vapor contact of three essential oils, and effects of environmental factors on their efficacy. Food Science and Technology, v.53, p.434-444, 2013. Available from: <https:/www.sciencedirect. com/science/article/pii/S0023643813001047>. Accessed: Mar. 16, 2020. doi: 10.1016/j.lwt.2013.03.012.

PRAKASH, B. et al. Assessment of chemically characterized Rosmarinus officinalis L. essential oil and its major compounds as plant-based preservative in food system based on their efficacy against food-borne moulds and aflatoxin secretion and as antioxidant. International Journal of Food Science and Technology, v.50, p.1792-1798, 2015. Available from: $<$ https://onlinelibrary.wiley.com/doi/full/10.1111/ijfs.12822>. Accessed: Mar. 16, 2020. doi: 10.1111/ijfs.12822.

PRAKASH, B. et al. Antifungal, anti-aflatoxin and antioxidant potential of chemically characterized Boswellia carterii Birdw essential oil and it's in vivo practical applicability in preservation of Piper nigrum L. fruits. LWT - Food Science and Technology, v.56, p.240-247, 2014. Available from: <https://www.sciencedirect. com/science/article/pii/S0023643813004945> . Accessed: Mar. 16, 2020. doi: 10.1016/j.lwt.2013.12.023.

RUSHING, B. R.; SELIM, M. I. Aflatoxin B: A review on metabolism, toxicity, occurrence in food, occupational exposure, and detoxification methods. Food and Chemical Toxicology, v.124, p.81-100, 2019. Available from: $<$ https://www.sciencedirect.com/science/article/pii/ S0278691518308494?via\%3Dihub>. Accessed: Mar. 16, 2020. doi: $10.1016 /$ j.fct.2018.11.047.

SAMAPUNDO, S. et al. Sorption isotherms and isosteric heats of sorption of whole yellow dent maize. Journal of Food Engineering, v.79, p.168-175, 2007. Available from: <https:// www.sciencedirect.com/science/article/pii/S0260877406001191>. Accessed: Mar. 16, 2020. doi: 10.1016/j.jfoodeng.2006.01.040.

SINGH, G. et al. Chemistry, antioxidant and antimicrobial investigations on essential oil and oleoresins of Zingiber officinale. Food and Chemical Toxicology, v.46, p.3295-3302, 2008. Available from: $<$ https://www.sciencedirect.com/science/article/ pii/S0278691508004110?via\%3Dihub>. Accessed: Mar. 16, 2020. doi: 10.1016/j.fct.2008.07.017.

SINHA, K. K. et al. (1993). The effect of clove and cinnamon oils on growth of and aflatoxin production by Aspergillus flavus. Letters in Applied Microbiology, 16, 114-117. Available from: $<$ https://sfamjournals.onlinelibrary.wiley.com/doi/abs/10.1111/ j.1472-765X.1993.tb01373.x>. Accessed: Mar. 16, 2020. doi: 10.1111/j.1472-765X.1993.tb01373.x.

SOARES, L. M. V.; RODRIGUEZ-AMAYA, D. B. Survey of aflatoxins, ochratoxin A, zearalenone and sterigmatocystin in some Brazilian foods by using multi-toxin thin-layer chromatographic method. Journal of the Association of Official Analytical 
Chemists, v.72, p.22-26, 1989. Available from: <https://www.ncbi. nlm.nih.gov/pubmed/2523887>. Accessed: Mar. 16, 2020.

SONKER, N. et al. Efficiency of Artemisia nilagirica (Clarke) Pamp. essential oil as a mycotoxicant against postharvest mycobiota of table grapes. Journal of the Science of Food and Agriculture, v.95, p.1932-1939, 2014. Available from: <https:// onlinelibrary.wiley.com/doi/full/10.1002/jsfa.6901>. Accessed: Mar. 16, 2020. doi: 10.1002/jsfa.6901.

THANABORIPAT, D. et al. Inhibition of aflatoxin production and growth of Aspergillus flavus by citronella oil. KMITL Science and Technology Journal, v.4, p.1-8, 2004. Available from: <https://s3.amazonaws.com/academia.edu. documents/6602540/inhibitionaflatoxin.pdf?response-contentdisposition=inline $\% 3 \mathrm{~B} \% 20$ filename $\% 3$ DInhibition_of_aflatoxin production_and_g.pdf\&X-Amz-Algorithm $=\mathrm{AW} \overline{\mathrm{W}} \overline{4}$-HMACSHA256\&X-Amz-Credential=AKIAIWOWYYGZ2Y53UL3A $\% 2$ F20200317\%2Fus-east-1\%2Fs3\%2Faws4_request\&X-Amz-
Date $=20200317 \mathrm{~T} 170714 Z \& X-A m z-E x p i r e s=3600 \& X-A m z-$ SignedHeaders $=$ host $\& X-A m z-$ Signature $=f 8 a e 31$ e2c254687beb67 d9a7fa3c9fedaf4253186b82b6464e2b2e207577e01c>. Accessed: Mar. 16, 2020.

WANG, H. et al. Antifungal evaluation of plant essential oils and their major components against toxigenic fungi. Industrial Crops and Products, v.120, p.180-186, 2018. Available from: $<$ https://www.sciencedirect.com/science/article/ pii/S0926669018303649>. Accessed: Mar. 16, 2020. doi: 10.1016/j.indcrop.2018.04.053.

YU,Y.etal.Development of gas chromatography-mass spectrometry with microwave distillation and simultaneous solid-phase microextraction for rapid determination of volatile constituents in ginger. Journal of Pharmaceutical and Biomedical Analysis, v.43, p.24-31, 2007. Available from: <https://www.sciencedirect. com/science/article/pii/S0731708506004432?via\%3Dihub>. Accessed: Mar. 16, 2020. doi: 10.1016/j.jpba.2006.06.037. 